MINERALOGIA, 41, No 1-2: 11-21 (2010)

DOI: $10.2478 / v 10002-010-0002-3$

www.Mineralogia.pl

MineRALOGICAL SocietY of Poland

Polskie TOWARZYSTWO MINERALOGICZNE

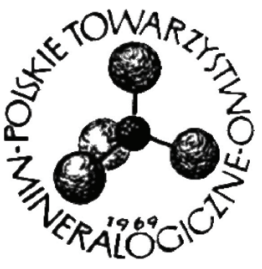

Original paper

\title{
Cobalt-rich lithiophorite from the Precambrian Eastern Ghats manganese ore deposit of Nishikhal, south Orissa, India
}

\author{
Danda S. RAO ${ }^{1 *}$, Bijaya K. NAYAK ${ }^{1}$, Bhaskar C. ACHARYA ${ }^{1}$ \\ ${ }^{\prime}$ Mineralogy Department, Institute of Minerals and Materials Technology, Bhubaneswar - 751 013, Orissa, India; \\ e-mail:dsrao@immt.res.in \\ * Corresponding author
}

Received: December 21, 2009

Received in revised form: October 20, 2010

Accepted November 4, 2010

Available online: November 20, 2010

\begin{abstract}
Fine-grained aggregates of lithiophorite are associated with cryptomelane, romanèchite, birnessite and graphite in the Precambrian Eastern Ghats manganese ore deposit of Nishikhal, south Orissa, India. High-cobalt lithiophorite is reported for the first time from the manganese ores. The mode of occurrence and the chemical composition of the lithiophorite are discussed. Along with manganese and aluminium, the lithiophorite contains appreciable quantities of $\mathrm{CoO}(1.59-8.56 \%)$ together with trace amounts of $\mathrm{Cu}, \mathrm{Ni}, \mathrm{Zn}, \mathrm{Ti}, \mathrm{Ca}, \mathrm{Mg}, \mathrm{Na}, \mathrm{K}$ and $\mathrm{P}$. The Nishikhal lithiophorite is a transition metal-rich lithiophorite.
\end{abstract}

Key-words: Nishikhal, manganese ore, lithiophorite, mineral chemistry

\section{Introduction}

The aluminous manganese oxide lithiophorite with the formula $(\mathrm{Al}, \mathrm{Li}) \mathrm{MnO}_{2}(\mathrm{OH})_{2}$ is common in the soils and weathering zones of manganese ore deposits. Apart from $\mathrm{Mn}, \mathrm{Al}$ and $\mathrm{Li}$, minor to trace amounts of $\mathrm{Fe}, \mathrm{Mg}, \mathrm{Ca}, \mathrm{K}, \mathrm{Si}, \mathrm{Cu}, \mathrm{Ni}, \mathrm{Co}$ and $\mathrm{Zn}$ are also present in lithiophorite (Roy 1981; Ostwald 1984, 1988). Lithiophorite in the Precambrian manganese ore deposits of Orissa has been reported by previous authors (Roy 1981; Acharya et al. 1997; Acharya, Nayak 1998; Acharya, Dash 2002; Mohapatra et al. 2005). The high Co 
content in lithiophorite from the manganese ores of Nishikhal $\left(19^{\circ} 12^{\prime}-19^{\circ} 14^{\prime} \mathrm{N} 83^{\circ} 12^{\prime}\right.$ $83^{\circ} 14^{\prime} \mathrm{E}$ ), Rayagada district, Orissa, India is reported here for the first time.

The manganese ores at Nishikhal are associated with khondalite, quartzite and calcsilicate granulite belonging to the Precambrian Eastern Ghats complex. The manganese ores and their host rocks were subjected to granulite facies metamorphism and experienced all of the deformational episodes typical of the Eastern Ghats complex before undergoing supergene enrichmernt (Acharya et al. 1997). The ores are highly variable in mineralogical composition and chemical constituents. Most are either ferruginous- or siliceous varieties with high phosphorous contents. They dominantly contain cryptomelane, romanèchite and pyrolusite with minor amounts of jacobsite, braunite, hausmannite, lithiophorite, birnessite and collophane. The other opaque minerals associated with the ores are goethite, magnetite, hematite, graphite, pyrite, sphalerite, chalcopyrite and the silicate gangue minerals include quartz, orthoclase, garnet (spessartite), apatite, collophane, kaolinite, plagioclase, hyalophane, fibrolite, zircon, biotite and muscovite (Acharya et al. 1994, 1997; Rao et al. 1994, 2008).

\section{Mineralogy and Chemical Characteristics}

\subsection{Mineralogy}

The lithiophorite is identified by its strong reflection pleochroism in dark to greyish white, low reflectivity (12.5-16.6\% at $546 \mathrm{~nm}$ in air), strong anisotropism and an average microhardness value of 65-83 (Vickers Hardness Number, VHN). It occurs as fine-grained aggregates with individual grains varying from $5-80 \mu \mathrm{m}$ and is dominant in high-grade massive and ferruginous/lateritised manganese ores. The lithiophorite occurs with cryptomelane, romanèchite, quartz and orthoclase in massive ore varieties, and in association with birnessite, goethite, kaolinite in ferruginous manganese ores. The lithiophorite replaces cryptomelane and silicate minerals and occasionally encloses quartz, orthoclase, garnet and cryptomelane (Fig. 1). It is also present along the cleavage planes of graphite and, in places, encloses graphite flakes (Fig. 2,3). The lithiophorite phase has been confirmed by an X-ray diffraction pattern with characteristic "d" values of 4.71, 3.14 and $2.37 \AA$ (Table 1).

\subsection{Mineral chemistry}

The lithiophorite phase associated with the Nishikhal manganese ores has been analysed on a JEOL, electron probe microanalyser (EPMA) Super Probe JXA-8600 (15 kV accelerating voltage and $2 \times 10^{-8} \mathrm{~mA}$ current) using SPI mineral standards and an on-line $\mathrm{ZAF}$ correction procedure. It contains (in wt.\%): 55.95-59.30\% $\mathrm{MnO}_{2}, 17.84-25.86 \%$ $\mathrm{Al}_{2} \mathrm{O}_{3}, 1.59-8.56 \% \mathrm{CoO}, 0.02-3.47 \% \mathrm{BaO}, 0.06-0.73 \% \mathrm{Fe}_{2} \mathrm{O}_{3}, 0.01-0.37 \% \mathrm{~K}_{2} \mathrm{O},<0.2 \%$ $\mathrm{Na}_{2} \mathrm{O}, 0.12-0.30 \% \mathrm{P}_{2} \mathrm{O}_{5}, 0.02-1.3 \% \mathrm{SiO}_{2}, 0.02-0.07 \% \mathrm{CaO}, 0.02-0.04 \% \mathrm{MgO}, 0.01-0.15 \%$ $\mathrm{TiO}_{2}, 0.06-0.14 \% \mathrm{CuO}, 0.04-0.25 \% \mathrm{NiO}$ and $0.06-0.35 \% \mathrm{ZnO}$ (Table 2). 


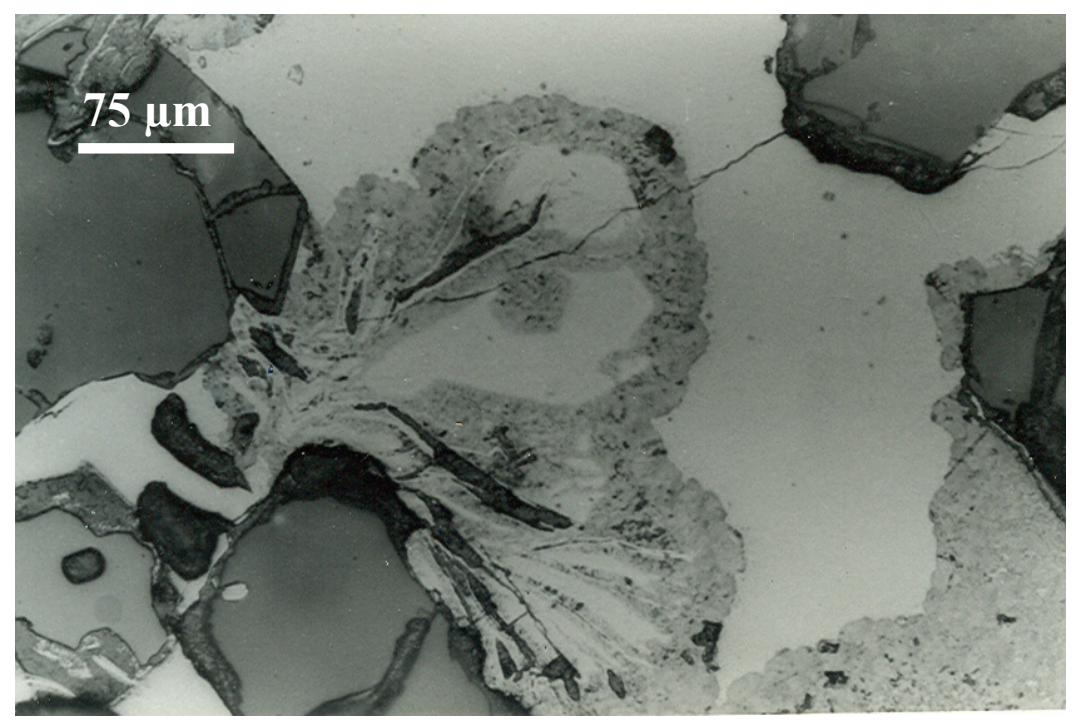

Fig. 1. Fine-grained aggregates of lithiophorite (grey) replaces cryptomelane (white) and encloses islands of the latter. Reflected light

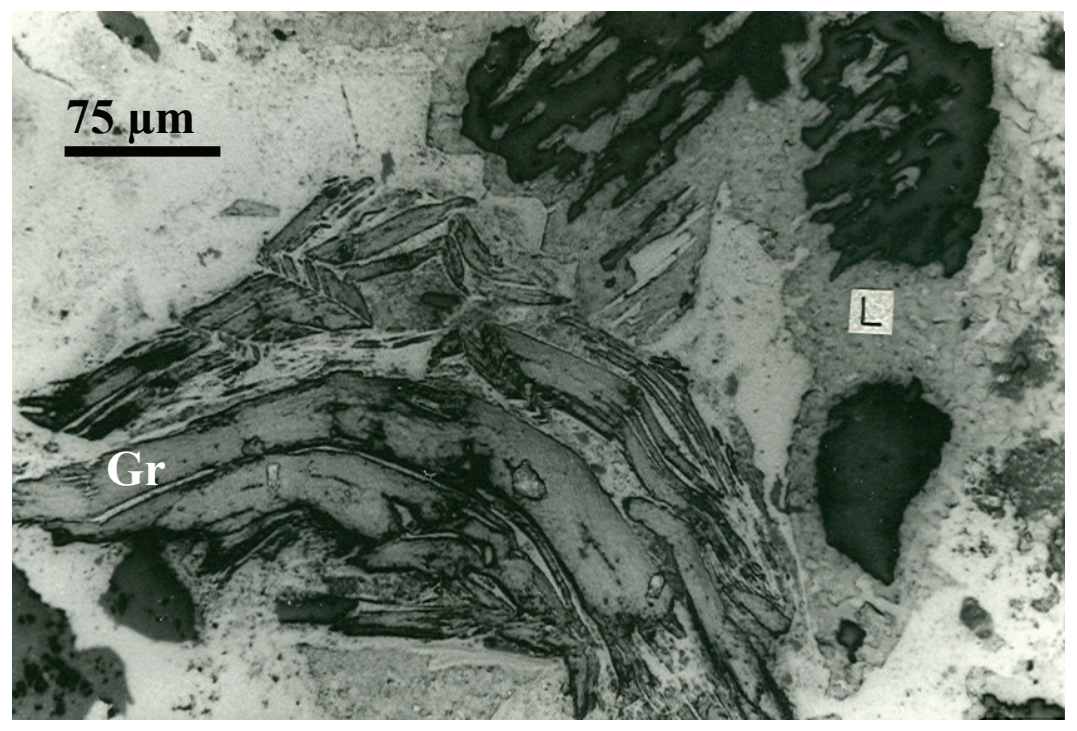

Fig. 2. Curved, kinked, folded flakes of graphite (Gr) enclosed by cryptomelane and lithiophorite (L). Cryptomelane replaces graphite along the cleavage and kink planes. Lithiophorite replaces cryptomelane and silicate gangue minerals. Reflected light 


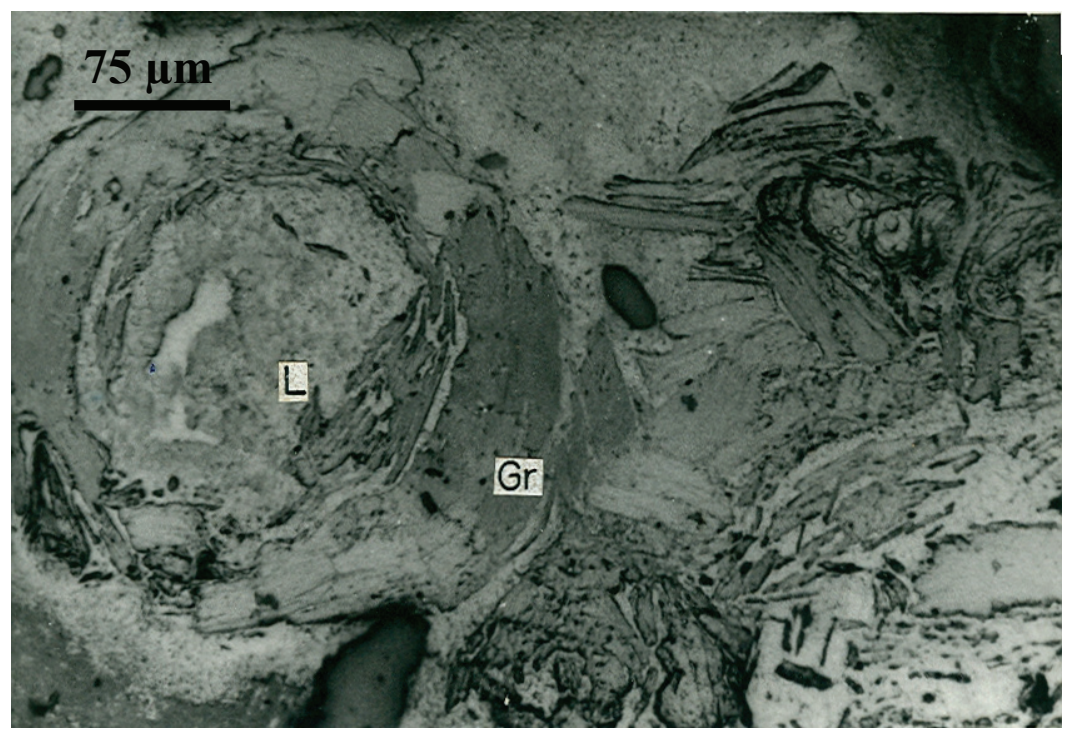

Fig. 3. Lithiophorite (L) and cryptomelane (white) present along cleavage planes of graphite (Gr) and enclosed within lithiophorite. Reflected light

The EPMA data for $\mathrm{MnO}_{2}$ and $\mathrm{Mn}_{2} \mathrm{O}_{3}$ and $\mathrm{Li}_{2} \mathrm{O}$ and $\mathrm{H}_{2} \mathrm{O}$ were recalculated. The recalculated values indicate that $\mathrm{Li}_{2} \mathrm{O}$ ranges from $2.90-5.80 \%$ and $\mathrm{H}_{2} \mathrm{O}$ from $12.64-14.32 \%$ (Table 2a). On the basis of these values, it is inferred that the second point analysis and the sixth point analysis of the EPMA data were accurate and involved lithiophorite exclusively. The remaining data $\left(1^{\text {st }}, 3^{\text {rd }}, 4^{\text {th }}\right.$ and $5^{\text {th }}$ points) involved mixtures with other phases as is indicated by high $\mathrm{MnO}_{2}$ and $\mathrm{BaO}$ contents (Table 2a). This is possible as microscopic studies indicate that the lithiophorite is fine-grained and intergrown with other manganese oxides.

De Villiers and Van Der Walt (1945) indicated formulae for lithiophorite based on wet chemical analyses for each of the two valence states of the manganese. Wadsley (1952) apparently arbitrarily adopted the formula with $\mathrm{Mn}^{+2}$ after Pauling and Kamb (1982). From a crystal chemical point of view, however, $\mathrm{Mn}^{3+}$ should be more easily accommodated into the lithiophorite structure (Post, Appleman 1994). Assuming trivalent Mn, the chemical analyses reported by De Villiers and Van Der Walt (1945) show just the right amounts of lower-valence $\mathrm{Mn}$ to offset the positive charges of the Li cations, i.e. one-third of the $\mathrm{Mn}$ sites are occupied by $\mathrm{Mn}^{3+}$.

$\mathrm{Co}$ and $\mathrm{Fe}$ may be substituting $\mathrm{Mn}$. The presence of $\mathrm{Co}^{+3}, \mathrm{Ni}^{+3}$ and $\mathrm{Cu}^{+2}$ lithiophorite may also be due to substitution of $\mathrm{Li}^{+}$by these elements because of their comparable ionic radii (Wilson et al. 1970; Ostwald 1984; Manceau et al. 1987; Plimer 1990). Transitionmetal oxide $(\mathrm{Cu}+\mathrm{Ni}+\mathrm{Zn}+\mathrm{Co})$ concentrations in the Nishikhal lithiophorite range from $1.98-9.22 \%$. Ostwald (1984) has classified lithiophorite from Australia as transition metalrich $(\mathrm{Cu}+\mathrm{Ni}+\mathrm{Zn}+\mathrm{Co}>1.5 \%)$ with $12-18 \% \mathrm{Al}_{2} \mathrm{O}_{3}$ and as transition metal poor $(\mathrm{Cu}+\mathrm{Ni}$ $+\mathrm{Zn}+\mathrm{Co}<1.5 \%$ ) with $18-24 \% \mathrm{Al}_{2} \mathrm{O}_{3}$. However, the Nishikhal lithiophorite, though having similar $\mathrm{Al}_{2} \mathrm{O}_{3}$ contents in the range 17.84-25.86\%, are enriched in transition metal oxide $(\mathrm{Cu}+\mathrm{Ni}+\mathrm{Zn}+\mathrm{Co}=1.98-9.22 \%)$. 
TABLE 1

XRD pattern of the lithiophorite-bearing sample

\begin{tabular}{|c|c|c|}
\hline $\mathrm{d} \AA$ & $\mathrm{I} / \mathrm{I}_{0}$ & Mineral Phases \\
\hline 7.09 & 17 & B \\
\hline 4.71 & 13 & $\mathrm{~L}$ \\
\hline 4.23 & 13 & $\mathrm{Q}, \mathrm{O}$ \\
\hline 3.78 & 6 & $\mathrm{O}$ \\
\hline 3.56 & 21 & $\mathrm{~B}$ \\
\hline 3.33 & 100 & $\mathrm{Q}, \mathrm{O}$ \\
\hline 3.14 & 4 & $\mathrm{~L}$ \\
\hline 2.51 & 9 & B \\
\hline 2.45 & 13 & Q \\
\hline 2.42 & 11 & B \\
\hline 2.37 & 15 & $\mathrm{~L}$ \\
\hline 2.28 & 10 & $\mathrm{Q}, \mathrm{L}$ \\
\hline 2.21 & 7 & B \\
\hline 2.15 & 7 & B \\
\hline 2.12 & 8 & Q \\
\hline 1.97 & 5 & $\mathrm{~B}$ \\
\hline 1.88 & 7 & $\mathrm{~L}$ \\
\hline 1.82 & 11 & $\mathrm{Q}, \mathrm{B}$ \\
\hline 1.77 & 4 & $\mathrm{~B}$ \\
\hline 1.67 & 13 & $\mathrm{Q}, \mathrm{B}$ \\
\hline 1.63 & 8 & $\mathrm{~B}$ \\
\hline 1.54 & 16 & Q \\
\hline 1.47 & 10 & $\mathrm{~B}$ \\
\hline 1.45 & 5 & Q,L \\
\hline 1.41 & 7 & $\mathrm{~B}$ \\
\hline 1.38 & 12 & $\mathrm{~L}, \mathrm{Q}$ \\
\hline
\end{tabular}

Abbreviations: B - Birnessite; L - Lithiophorite; O - Orthoclase; Q - Quartz. 
TABLE 2

Electron probe analyses of lithiophorite from the Nishikhal manganese ores (in wt.\%)

\begin{tabular}{|c|c|c|c|c|c|c|}
\hline \multirow{2}{*}{ Component } & \multicolumn{6}{|c|}{ Nishikhal lithiophorite } \\
\hline & 1 & 2 & 3 & 4 & 5 & 6 \\
\hline $\mathrm{MnO}_{2}$ & 59.30 & 59.74 & 57.90 & 56.19 & 57.21 & 55.95 \\
\hline $\mathrm{Fe}_{2} \mathrm{O}_{3}$ & 0.14 & 0.06 & 0.67 & 0.73 & 0.06 & 0.07 \\
\hline $\mathrm{SiO}_{2}$ & 0.02 & 0.07 & 1.33 & 1.32 & 0.43 & 0.06 \\
\hline $\mathrm{Al}_{2} \mathrm{O}_{3}$ & 25.86 & 23.18 & 22.92 & 22.32 & 17.84 & 25.75 \\
\hline $\mathrm{Na}_{2} \mathrm{O}$ & 0.02 & 0.00 & ND & ND & 0.02 & ND \\
\hline $\mathrm{K}_{2} \mathrm{O}$ & 0.01 & 0.03 & 0.13 & 0.14 & 0.37 & 0.01 \\
\hline $\mathrm{CaO}$ & 0.02 & 0.06 & 0.07 & 0.05 & 0.07 & 0.03 \\
\hline $\mathrm{MgO}$ & 0.02 & 0.04 & 0.03 & 0.03 & 0.03 & 0.03 \\
\hline $\mathrm{TiO}_{2}$ & 0.07 & 0.02 & 0.09 & 0.01 & 0.15 & 0.06 \\
\hline $\mathrm{P}_{2} \mathrm{O}_{5}$ & 0.13 & 0.13 & 0.13 & 0.12 & 0.30 & 0.18 \\
\hline $\mathrm{CuO}$ & 0.11 & 0.06 & 0.12 & 0.14 & 0.06 & 0.07 \\
\hline $\mathrm{CoO}$ & 3.88 & 1.59 & 8.02 & 8.56 & 4.34 & 3.62 \\
\hline $\mathrm{NiO}$ & 0.04 & 0.11 & 0.22 & 0.25 & 0.11 & 0.04 \\
\hline $\mathrm{ZnO}$ & 0.10 & 0.22 & 0.22 & 0.27 & 0.35 & 0.06 \\
\hline $\mathrm{BaO}$ & 0.09 & 0.03 & 0.99 & 1.00 & 3.47 & 0.02 \\
\hline $\mathrm{CuO}+\mathrm{CoO}+\mathrm{NiO}+\mathrm{ZnO}$ & 4.12 & 1.98 & 8.58 & 9.22 & 4.86 & 3.79 \\
\hline
\end{tabular}

TABLE $2 \mathrm{a}$

Recalculation of electron probe data for various elements and their structural formulas

\begin{tabular}{ccccccc}
\hline & 1 & 2 & 3 & 4 & 5 & 6 \\
\hline $\mathrm{MnO}_{2}$ & 39.67 & 41.63 & 54.19 & 46.29 & 53.87 & 33.51 \\
$\mathrm{Mn}_{2} \mathrm{O}_{3}$ & 18.02 & 16.63 & 3.40 & 9.09 & 3.09 & 20.61 \\
$\mathrm{Fe}_{2} \mathrm{O}_{3}$ & 0.14 & 0.06 & 0.67 & 0.73 & 0.06 & 0.07 \\
$\mathrm{SiO}_{2}$ & 0.02 & 0.07 & 1.33 & 1.32 & 0.43 & 0.06 \\
$\mathrm{Al}_{2} \mathrm{O}_{3}$ & 25.86 & 23.18 & 22.92 & 22.32 & 17.84 & 25.75 \\
$\mathrm{Na}_{2} \mathrm{O}$ & 0.02 & 0.00 & 0.00 & 0.00 & 0.02 & 0.00 \\
$\mathrm{~K}_{2} \mathrm{O}$ & 0.01 & 0.03 & 0.13 & 0.14 & 0.37 & 0.01 \\
$\mathrm{CaO}$ & 0.02 & 0.06 & 0.07 & 0.05 & 0.07 & 0.03 \\
\hline
\end{tabular}


TABLE 2a cont.

\begin{tabular}{|c|c|c|c|c|c|c|}
\hline $\mathrm{MgO}$ & 0.02 & 0.04 & 0.03 & 0.03 & 0.03 & 0.03 \\
\hline $\mathrm{TiO}_{2}$ & 0.07 & 0.02 & 0.09 & 0.01 & 0.15 & 0.06 \\
\hline $\mathrm{P}_{2} \mathrm{O}_{5}$ & 0.13 & 0.13 & 0.13 & 0.12 & 0.30 & 0.18 \\
\hline $\mathrm{CuO}$ & 0.11 & 0.06 & 0.12 & 0.14 & 0.06 & 0.07 \\
\hline $\mathrm{Co}_{2} \mathrm{O}_{3}$ & 4.30 & 1.76 & 8.88 & 8.50 & 4.81 & 4.00 \\
\hline $\mathrm{NiO}$ & 0.04 & 0.11 & 0.22 & 0.25 & 0.11 & 0.04 \\
\hline $\mathrm{ZnO}$ & 0.10 & 0.22 & 0.22 & 0.27 & 0.35 & 0.06 \\
\hline $\mathrm{BaO}$ & 0.09 & 0.03 & 0.99 & 1.00 & 3.47 & 0.02 \\
\hline $\mathrm{Li}_{2} \mathrm{O}$ & 3.55 & 3.55 & 4.70 & 5.00 & 5.80 & 2.90 \\
\hline \multirow[t]{2}{*}{$\mathrm{H}_{2} \mathrm{O}$} & 13.44 & 12.74 & 14.32 & 14.18 & 13.60 & 12.64 \\
\hline & 105.61 & 100.32 & 112.41 & 109.44 & 104.43 & 100.04 \\
\hline \multicolumn{7}{|c|}{ Formula based on $4(\mathrm{O})$} \\
\hline $\mathrm{Al}$ & 0.680 & 0.643 & 0.566 & 0.556 & 0.464 & 0.720 \\
\hline $\mathrm{Li}$ & 0.319 & 0.336 & 0.396 & 0.425 & 0.515 & 0.277 \\
\hline $\mathrm{Si}$ & 0.000 & 0.002 & 0.028 & 0.028 & 0.010 & 0.001 \\
\hline $\mathrm{Si}+\mathrm{Li}+\mathrm{Al}$ & 0.999 & 0.980 & 0.989 & 1.010 & 0.989 & 0.998 \\
\hline $\mathrm{Mn}^{4+}$ & 0.612 & 0.677 & 0.784 & 0.821 & 0.873 & 0.550 \\
\hline $\mathrm{Mn}^{3+}$ & 0.306 & 0.298 & 0.054 & 0.000 & 0.000 & 0.372 \\
\hline $\mathrm{Na}$ & 0.001 & 0.000 & 0.000 & 0.000 & 0.001 & 0.000 \\
\hline K & 0.000 & 0.001 & 0.003 & 0.004 & 0.010 & 0.000 \\
\hline $\mathrm{Ca}$ & 0.000 & 0.002 & 0.002 & 0.001 & 0.002 & 0.001 \\
\hline $\mathrm{Mg}$ & 0.001 & 0.001 & 0.001 & 0.001 & 0.001 & 0.001 \\
\hline $\mathrm{Ti}^{4+}$ & 0.001 & 0.000 & 0.001 & 0.000 & 0.003 & 0.001 \\
\hline $\mathrm{P}^{5+}$ & 0.002 & 0.003 & 0.002 & 0.002 & 0.006 & 0.004 \\
\hline $\mathrm{Co}^{3+}$ & 0.069 & 0.030 & 0.135 & 0.130 & 0.077 & 0.069 \\
\hline $\mathrm{Ni}^{2+}$ & 0.001 & 0.002 & 0.004 & 0.004 & 0.002 & 0.001 \\
\hline $\mathrm{Zn}^{2+}$ & 0.002 & 0.004 & 0.003 & 0.004 & 0.006 & 0.001 \\
\hline $\mathrm{Ba}^{2+}$ & 0.001 & 0.000 & 0.008 & 0.008 & 0.030 & 0.000 \\
\hline $\mathrm{OH}$ & 2.001 & 1.999 & 2.000 & 2.000 & 2.003 & 2.000 \\
\hline $\mathrm{Cu}^{2+}$ & 0.002 & 0.001 & 0.002 & 0.002 & 0.001 & 0.001 \\
\hline $\mathrm{Fe}^{3+}$ & 0.002 & 0.001 & 0.011 & 0.012 & 0.001 & 0.001 \\
\hline
\end{tabular}

Among the transition elements, Co is the dominant constituent. The fine-grained Nishikhal lithiophorites contain elevated amounts of $\mathrm{Co}$ as do the manganese oxides from the Fort Payne Formation, Tennessee (Larson 1970). The Co and Ni contents are higher than those reported in lithiophorite from manganese ores in the Bonai-Keonjhar belt, Orissa, India (Mohapatra et al. 2005) and lower than in lithiophorite (13.57-14.58\% CoO 
and $7.67-14.54 \% \mathrm{NiO}$ ) in nickeliferous laterites from Sukinda, Orissa, India (Das et al. 2002; Mohanty et al. 2000). Compared to that in the Sandur manganese ores, Karnataka, India (Mohapatra et al. 1996), the $\mathrm{Co}, \mathrm{Cu}, \mathrm{Ni}$ and $\mathrm{Zn}$ contents in the lithiophorite described here are higher.

\subsection{Chemical characteristics of the manganese ores}

Partial chemical analyses of 19 manganese ore samples representing high grade-, siliceous- and ferruginous varieties from the Nishikhal deposit are given in Table 3. The data show that they contain $4.11-89.27 \% \mathrm{MnO}_{2}, 1.66-80.15 \% \mathrm{Fe}_{2} \mathrm{O}_{3}, 0.01-49.75 \% \mathrm{SiO}_{2}$, $0.89-5.71 \% \mathrm{Al}_{2} \mathrm{O}_{3}$ and $0.06-0.22 \% \mathrm{Li}_{2} \mathrm{O}$. Generally, manganese-rich samples are rich in lithium. Li shows a strong positive correlation with $\mathrm{MnO}_{2}$ (Fig. 4) and a weak positive correlation with $\mathrm{Al}_{2} \mathrm{O}_{3}$ (Fig. 5). The weak correlation of alumina with lithium oxide reflects the fact that most of the alumina in the ores is contributed by silicates such as orthoclase, kaolinite and garnet. Lithium shows negative correlations with $\mathrm{Fe}_{2} \mathrm{O}_{3}$ and $\mathrm{SiO}_{2}$. The data suggest the preferential linkage of lithium with manganese and aluminium. In the Nishikhal manganese ores, $\mathrm{Co}, \mathrm{Ni}$ and $\mathrm{Zn}$ are positively correlated with $\mathrm{MnO}_{2}$ (Acharya et al. 1997).

TABLE 3

Partial chemical analyses of Nishikhal manganese ores

\begin{tabular}{ccccccc}
\hline & $\begin{array}{c}\text { Sample } \\
\text { number }\end{array}$ & $\mathrm{MnO}_{2}$ & $\mathrm{Fe}_{2} \mathrm{O}_{3}$ & $\mathrm{SiO}_{2}$ & $\mathrm{Al}_{2} \mathrm{O}_{3}$ & $\mathrm{Li}_{2} \mathrm{O}$ \\
\hline \multirow{5}{*}{ High grade } & 1 & 89.27 & 4.26 & 0.05 & 4.14 & 0.17 \\
manganese ores & 2 & 83.39 & 10.05 & 2.97 & 4.05 & 0.22 \\
& 3 & 83.04 & 0.83 & 1.17 & 1.85 & 0.14 \\
& $4^{*}$ & 82.21 & 1.95 & 0.2 & 1.27 & 0.14 \\
& 6 & 76.51 & 9.59 & 0.15 & 1.10 & 0.12 \\
Average & 72.19 & 7.78 & 0.15 & 4.40 & 0.20 \\
Siliceous & 81.10 & 5.74 & 0.78 & 2.80 & 0.165 \\
\hline manganese ores & 8 & 48.05 & 4.65 & 34.79 & 4.02 & 0.15 \\
& 9 & 42.05 & 1.66 & 49.75 & 5.07 & 0.11 \\
& 10 & 35.89 & 4.18 & 38.69 & 5.71 & 0.07 \\
& 11 & 58.44 & 4.24 & 30.12 & 3.89 & 0.16 \\
& Average & 46.14 & 5.79 & 27.74 & 3.71 & 0.19 \\
& $12 *$ & 4.76 & 69.60 & 6.61 & 5.33 & 0.09 \\
Ferruginous & 13 & 4.72 & 80.15 & 0.01 & 0.89 & 0.10 \\
manganese ores & 14 & 22.72 & 56.61 & 0.05 & 3.10 & 0.15 \\
& 14 & 9.82 & 54.71 & 0.05 & 1.91 & 0.06 \\
& 16 & 4.11 & 39.01 & 48.73 & 2.21 & 0.06 \\
& 17 & 27.92 & 36.42 & 0.09 & 2.81 & 0.13 \\
& 18 & 24.85 & 20.16 & 8.33 & 1.17 & 0.09 \\
& 19 & 51.61 & 19.18 & 4.60 & 3.33 & 0.16 \\
& Average & 18.81 & 46.98 & 8.56 & 2.59 & 0.11 \\
\hline
\end{tabular}

* From: Acharya et al. (1997). 


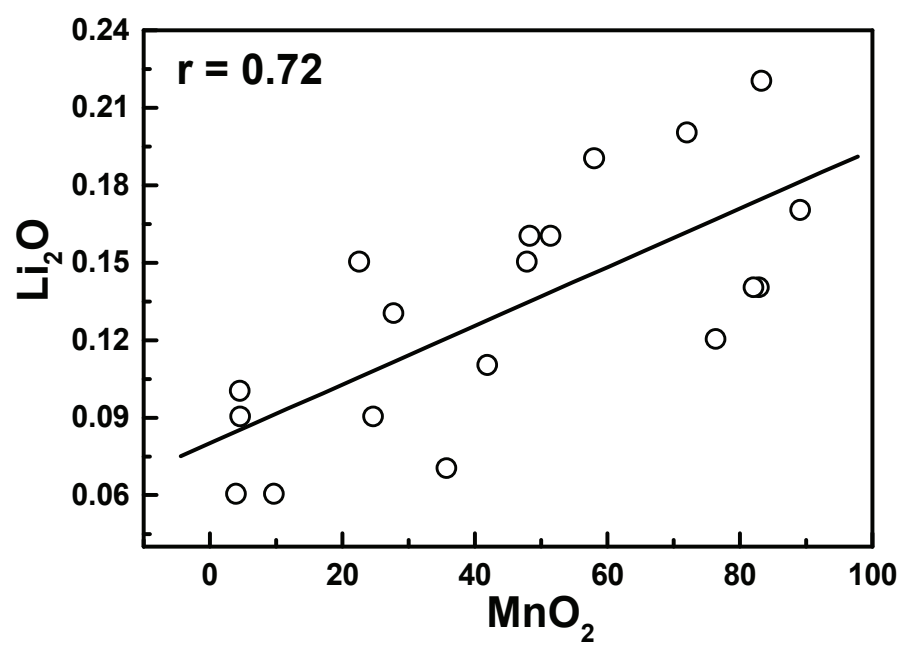

Fig. 4. Plot of $\mathrm{MnO}_{2}$ vs. $\mathrm{Li}_{2} \mathrm{O}$ showing positive correlation

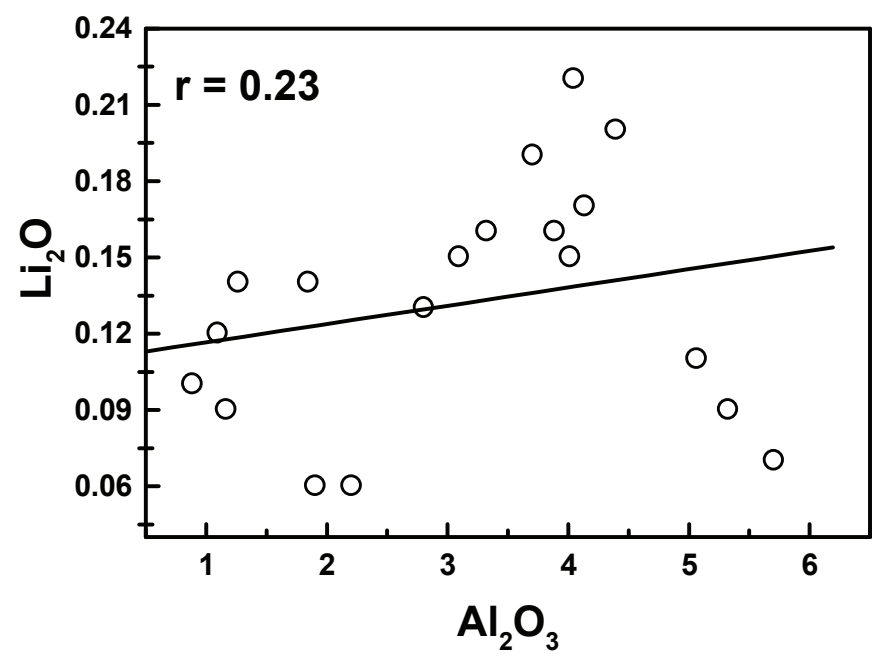

Fig. 5. Plot of $\mathrm{Al}_{2} \mathrm{O}_{3}$ vs. $\mathrm{Li}_{2} \mathrm{O}$ showing weak positive correlation indicating $\mathrm{Li}_{2} \mathrm{O}$ and $\mathrm{Al}_{2} \mathrm{O}_{3}$ contributed by lithiophorite

\section{Discussion and Conclusions}

The Nishikhal manganese deposit represents the syngenetic part of the metasedimentary sequence of the Precambrian Eastern Ghats complex. The manganese-rich sediments were metamorphosed under granulite facies conditions, affected by granitisation and subsequently underwent supergene enrichment (Acharya et al. 1997). Under supergene processes, lithiophorite along with pyrolusite, cryptomelane, romanèchite, birnessite and goethite were formed from the primary manganese minerals of lower valency states such as spessartite, braunite, jacobsite and hausmannite. A low-temperature reaction between 
primary manganese oxides including spessartite and clay minerals can produce lithiophorite and birnessite (Ostwald 1988; Nahon et al. 1984). The aluminium content in the lithiophorite is much higher than that of the primary manganese oxides and silicate minerals. The aluminium in the structure enhances the stability of lithiophorite and is the final product of weathering (Dowding, Fey 2007).

The Nishikhal lithiophorite is enriched in cobalt $(<8.56 \% \mathrm{CoO})$. It has a high aluminium content comparable with that of lithiophorite from New Caledonia (Llorca, Monchoux 1991). The primary manganese minerals in the Precambrian Eastern Ghats complex contain very small $(\mathrm{Co}<1 \%)$ contents of cobalt (Acharya et al. 1997; Acharya, Nayak 1998; Acharya, Dash 2002). During the supergene processes, lithiophorite formed from the primary manganese oxides and silicates. In the lithiophorite, cobalt, nickel, copper and zinc are enriched with cobalt being especially so at $1.59-8.56 \%$ CoO. Cobalt in manganese shows a good correlation with manganese. A similar correlation has been reported from the laterites of the Lomie region, south-east Cameroon (Yongue-Fouateu et al. 2006). Lithiophorite is the main contributor of cobalt as the bulk manganese ores contain very small amounts.

The Nishikhal manganese ores contain lithia $(<0.22 \%)$ present in the form of finegrained lithiophorite. The deposit contains more than 10 million tonnes of manganese ores. The lithiophorite, if separated from the manganese ores, can represent a potential resource of both $\mathrm{Co}$ and $\mathrm{Li}$.

Acknowledgements. The authors are indebted to the staff of Indian Institute of Technology, Roorkee and M/s. Orissa Mining Corporation Ltd., for EPMA analyses and help in the field respectively. The authors are grateful to the Director, IMMT, Bhubaneswar for his kind permission to publish this article. Thanks are also due to Prof. Evgeny Galuskin, Poland, for his critical comments and suggestions which have greatly helped to improve this manuscript.

\section{References}

Acharya, B.C., Rao, D.S., Sahoo, R.K., \& Dash, B. (1994). Phosphorous in the siliceous manganese ores of Nishikhal, Orissa. Indian Journal of Geology 66(1),15-23.

Acharya, B.C., Rao, D.S., \& Sahoo, R.K. (1997). Mineralogy, chemistry and genesis of Nishikahl manganese ores of south Orissa, India. Mineralium Deposita 32(1),79-93.

Acharya, B.C., \& Nayak, B.K. (1998). Mineral chemistry of manganese ores associated with Precambrian Eastern Ghats complex of Andhra Pradesh-Orissa, India. Journal of Mineralogy, Petrology and Economic Geology 93(6), 214-231.

Acharya, B.C., \& Dash, K.K. (2002). Mineralogical and geochemical characteristics of manganese ores associated with the Precambrian Eastern Ghats Complex in Bolangir District, Orissa. Indian Journal of Geology 74(1-4), $115-144$.

Das, S.K., Rajeev, Acharya, B.S., Muralidhar, J., \& Sahoo, R.K. (2002). Characterisation of bulk nickeliferous laterites of Sukinda, Orissa. Indian Journal of Geology 74(1-4), 249-260.

De Villers, J.E., \& Van der Walt, C.G.J. (1945). Lithiophorite from the Postmasburg manganese deposits. American Mineralogist 30, 629-634.

Dowding, C.E., \& Fey, M.V. (2007). Morphological, chemical and mineralogical properties of some manganeserich oxisols derived from dolomite in Mpumalanga province, South Africa. Geoderma 141(1-2), 23-33.

Larson, L.T. (1970). Cobalt and nickel bearing manganese oxides from the Fort Payne Formation, Tennessee. Economic Geology 65, 952-962. 
Llorca, S., \& Monchoux, P. (1991). Supergene cobalt minerals from New Caledonia. Canadian Mineralogist 29, 149-161.

Manceau, A., Llorca, S., \& Calas, G. (1987). Crystal chemistry of cobalt and nickel in lithiophorites and asbolane from New Caledonia. Geochimica et Cosmochimica Acta 51(1), 105-113.

Mohanty, J.K., Rao, D.S., Das, B., \& Rao, R.B. (2000). Mineralogy and pre-concentration of the chromite overburden of the Sukinda Ultramafic Belt, Orissa, India. CIM Magazine 93(1038), 37-43.

Mohapatra, B.K., Rao, D.S., Nayak, B.D., \& Sahoo, R.K. (1996). Mineralogical and chemical characteristics of ferromanganese ores from Sandur, Karantaka, India. Journal of Mineralogy, Petrology and Economic Geology 91(2), 48-61.

Mohapatra, B.K., Mishra, P.P., Singh, P.P., Paul, A.K., \& Rajeev (2005). Co-rich lithiophorite in manganese Ores of the Bonai-Keonjhar Belt, Orissa. Journal of The Geological Society of India 66, 407-412.

Nahon, D., Beauvis, A., Nziengui-Mapangou, P., \& Ducloux, J. (1984). Chemical weathering of Mn-garnet under lateritic conditions in North-West Ivory coast, (West Africa). Chemical Geology 45(1-2), 53-71.

Ostwald, J. (1984). Two varieties of lithiophorite in some Australian deposits. Mineralogical Magazine 48, 385392.

Ostwald, J. (1988). Mineralogy of the Groote Eylandt manganese oxides: A review. Ore Geol. Reviews 4(1), 3-45.

Pauling, L., \& Kamb, B. (1982). The crystal structure of lithiophorite. American Mineralogist 67, 817-821.

Plimer, I.R. (1990). Rare earth element enriched cobaltiferous wads, Bungonia, eastern Australia. Geologische Rundschau, Stuttagart 79(2), 171-182.

Post, J.E., \& Appleman, D.E. (1994). Crystal structure refinement of lithiophorite. American Mineralogist 79(3-4), 370-374.

Rao, D.S., Acharya, B.C., \& Sahoo, R.K. (1994). Pyrophanite from Nishikhal manganese deposit, Orissa. Journal of The Geological Society of India 44(1), 91-93.

Rao, D.S., Acharya, B.C., \& Nayak, B.K. (2008). Hyalophane from Nishikhal manganese deposit, Orissa. Vistas in Geological Research. Utkal University Special Publication in Geology 7, 63-65.

Roy, S. (1981). Manganese deposits. London: Academic Press.

Wadsley, A.D. (1952). The structure of lithiophorite (Al, Li) $\mathrm{MnO}_{2}(\mathrm{OH})_{2}$. Acta Crystallographica 5, 676-680.

Wilson, M.J., Berrow, M.L., \& McHardy, W. (1970). Lithiophorite from the Lecht Mines, Tomintoul, Banffshire. Mineralogical Magazine 37, 618-623.

Yongue-Fouateu, R., Ghogomu, R.T., Penaye, J., Ekodeck, G.E., Stendal, H., \& Colin, F. (2006). Nickel and cobalt distribution in the laterites of the Lomie region, south-east Cameroon. Journal of African Earth Sciences 45(1), 33-47. 
